\title{
ПРОБЛЕМАТИКА РОЗМЕЖУВАННЯ ПЛАГІАТУ ТА ПОРУШЕННЯ У СФЕРІ АВТОРСЬКОГО ПРАВА І ЇЇ ВІДОБРАЖЕННЯ В СУДОВИХ ПРЕЦЕДЕНТАХ У СФЕРІ ЛІТЕРАТУРНОЇ ТВОРЧОСТІ
}

Анотація. Статтю присвячено співвідношенню та відмінності плагіату та порушення авторського права.
Значення такого розмежування на фоні науково-технологічного розвитку суспільства. Важливість на-
лежного правового захисту інтелектуального потенціалу в умовах інноваційних процесів. Доступність
результатів творчості в теперішній цифровий час є однією з основних причин виникення плагіату і по-
рушень авторських прав. Сьогодні творчість людей є головною рушійною силою у прогресі суспільства.
Порушення у сфері авторського права не завжди матимуть виключно матеріальні наслідки, але можуть
призвести до втрати репутації, а сама робота буде позбавлена ексклюзивності та певної індивідуалізації.
Також розглянуті дві судові суперечки щодо авторського права стосовно серії книг у сфері літературної
творчості Джоан Роулінг.
Ключові слова: авторсье право, плагіат, порушення авторських прав, захист авторського права, похідний твір.

Torhashova Kateryna

Yaroslav Mudryi National Law University

\section{PROBLEMS OF DISTINGUISHING PLAGIARISM AND COPYRIGHT INFRINGEMENTS AND ITS REFLECTION IN JUDICIAL CASES IN THE FIELD OF LITERATURE}

Summary. The article is devoted to the relationship and differences between plagiarism and copyright infringement. The significance of such a distinction against the background of scientific and technological development of society. The importance of proper legal protection of intellectual potential in terms of innovation processes. The availability of creative results in the current digital age is one of the main causes of plagiarism and copyright infringement. Today, people's creativity is the main driving force in the progress of society. Copyright infringements will not always have purely material consequences, but may lead to loss of reputation, and the work itself will be deprived of exclusivity and some individualization. One of the most common problems of today in scientific and technological development is infringement of intellectual property rights. Protecting the rights of citizens of any country, whose efforts are aimed at forming works of literature, science and art - is one of the priority tasks of any state. Instead, one of the most common forms of copyright infringement is unscrupulous borrowing of works, namely plagiarism. At the same time, concepts such as "plagiarism" and "copyright infringement" may be the same, but they are not the same. You can plagiarize without infringing copyright and you can infringe copyright without plagiarizing. Of course, this phenomenon is manifested in multidimensional manifestations. In any case, such borrowing, in addition to the offense, will also be considered a breach of ethics, and may damage the reputation of the author. At the same time, we must distinguish between the concepts of "copyright infringement" and "plagiarism". Due to the fact that in modern realities there is a huge number of copyright infringements - this leads to a large number of lawsuits, the details of which are of great practical and scientific interest. That is why this topic is extremely relevant. Two copyright disputes were also considered over a series of books in the field of literary works by Joan Rowling.

Keywords: copyright, plagiarism, copyright infringement, copyright protection, derivative work.

$\Pi^{2}$ остановка проблеми. Однією 3 найпоширеніших проблем сучасності в умовах науково-технічного розвитку є порушення прав у сорері інтелектуальної власності. Захист прав громадян будь-якої країни, зусилля яких спрямовані на формування творів літератури, науки та мистецтва - $є$ одним з першочергових завдань будь-якої держави. Натомість, однією з поширених фрорм порушень у сфрері авторського права $є$ недобросовісне запозичення творів, а саме плагіат. Безумовно, таке явище проявляеться в багатовимірних проявах. В будь якому випадку таке запозичення, окрім правопорушення, також вважатиметься і порушенням етики, а також може завдати шкоди репутації автора. Водночас ми повинні розрізняти поняття «порушення авторського права» і «плагіат».

Зважаючи на те, що в сучасних реаліях відбувається величезна кількість порушень автор- ського права, - це призводить до великої кількості судових справ, деталі яких мають важливий практичний та науковий інтерес. Саме тому дана тематика є надзвичайно актуальною.

Аналіз останніх досліджень і публікацій. Питанню дослідження авторського права і належного захисту авторських прав присвячувалось чимало наукових праць. Зокрема, дана тематика була об’єктом дослідження таких вітчизняних дослідників як I.Н. Азімов, Г.В. Закорецька, Г.А. Андрощук, Р.О. Стефранчук, С.В. Дяченко та багатьох інших.

Виділення невирішених раніше частин загальної проблеми. Незважаючи на певні дослідження даної тематики, існуе все ще певна невизначеність розмежування понять «плагіат» та «порушення у сорері авторського права", які можуть як збігатися, так і бути окремими правопорушеннями. Правильне розмежування дозво- 
лить визначити і належних суб'єктів, що можуть бути притягнені до відповідальності.

Метою статті є дослідження проблематики розмежування понять «плагіат» та «порушення у сорері авторського права", на прикладі декількох зарубіжних судових справ у сфрері літературної творчості.

Виклад основного матеріалу. Семантика поняття плагіату досить розширена. Як приклад, Оксфордський словник англійської мови визначає плагіат як «неправомірне привласнення» та навіть «крадіжку і публікацію» мови іншого автора, думок, ідей чи виразів та представлення їх як власної оригінальної роботи. Закон України «Про авторське право і суміжні права» визначає, що плагіат - це оприлюднення (опублікування), повністю або частково, чужого твору під іменем особи, яка не $є$ автором цього твору. Сама тенденція так званого "несанкціонованого використання» творів з'явилася ще за доби античності [8, с. 268-270].

Такі поняття як «плагіат» i «порушення авторського права" можуть збігатися, однак це не $€$ однакові поняття. Можна плагіатувати, не порушуючи авторських прав та можна порушувати авторські права, не плагіатуючи [1, с. 1-3].

Плагіат є етичною конструкцією, а порушення авторського права буде визначатися саме правовою конструкцією. Наслідки плагіату можуть зачіпати не лише автора певної роботи, а інших осіб, читачів, наприклад, яких ввели в так звану оману, адже був представлений твір під іменем особи, яка не є автором цього твору. Особа може плагіатувати майже все, включаючи те, що не захищено авторським правом. Наприклад, якщо би конкретна особа заявила про те, що вона $є$ автором однієї з п'єси Вільяма Шекспіра - це був би саме плагіат, адже ці п'єси вже є загальнодоступними і не захищеними авторським правом. Більш того, навіть якщо брати дозвіл на використання певних робіт, то це не буде порушенням авторського права, але все ще буде плагіатом. Плагіат можна охарактеризувати як «інтелектуальну недоброчесність»; - не завжди це призводитиме до очевидних матеріальних наслідків, на відміну від порушення авторського права. Якщо говорити про певні часові обмеження, які існують в авторському праві, то стосовно плагіату таких обмежень не існуе. I певну відповідальність у випадку плагіату може визначити не лише суд, але й конкретні академічні установи чи певні комісії 3 питань етики [9, с. 19-21].

Якщо говорити саме про порушення авторського права, то тут вже буде поставати питання запозичення твору власника без дозволу і спричинятиме саме юридичні наслідки. Можна сказати, що порушення авторських прав може включати широкий діапазон таких порушень [6, c. 297-271].

Тобто, можна стверджувати, що плагіат не завжди є порушенням авторського права, а порушення авторського права не завжди є плагіатом.

Досить цікаві судові випадки порушення авторського права у сфрері літературної творчості існують на прикладі судової системи США. Так, спочатку можна виділити теми головних спорів у сорері порушення авторського права, які найчастіше розглядаються американськими судами: питання, які виникають стосовно попередніх робіт позивача; питання подібності робіт позивача та відповідача; питання доступу до роботи позивача; питання привласнення захищеного твору відповідачем; намір відповідача привласнити певну роботу; збитки позивача внаслідок привласнення роботи відповідачем та питання оригінальності.

В контексті даної статті будуть розглядатися справи саме пов'язані з питаннями подібності робіт позивача та відповідача, а також питання доступу та привласнення робіт позивача.

В першому випадку, якщо говорити про подібність, слід наголосити, що сам фракт подібності, безсумнівно, не є доказом літературного плагіату. Конкретно дві взяті роботи можуть бути достатньо подібними, однак в той же час бути створені незалежно одна від одної. Тому, сам фракт лише подібності не є порушенням. Суди, звісно, не виключають, що подібність не завжди може бути збігом обставин. Але, в кожному конкретному випадку, слід говорити не про існування «суттєвих" подібностей, а про існування "виняткових» подібностей. Звісно, дані поняття є досить суб'єктивними і оціночними, але таким чином побудована судова практика.

Стосовно можливості доступу відповідача до робіт позивача, таке твердження може бути спростованим відсутністю доказів до конкретних матеріалів. Однак подання такого доказу може бути досить проблематичним, зважаючи на те, що непрямі докази не завжди будуть братися до уваги судом. В даному випадку суди будуть виходити 3 принципу: «Чим більше подібності, тим простіше доказ доступу» [7, с. 181, 183-185].

Переходячи до розгляду конкретних судових справ, слід зазначити численну судову практику стосовно творчості Джоан Роулінг, оскільки їі серія романів про Гаррі Поттера характеризуеться десятками прецедентних справ у сфрері порушення авторських прав, суперечками стосовно Першої поправки щодо релігійних висловлювань (США) та іншими ситуащіями [2, с. 1-4].

Перша цікава справа буде стосуватися 1991 року - року виходу першої книги із серії Гаррі Поттера Джоан Роулінг в США - та стосуватиметься саме питанню подібності та доступу.

У 1980 році американська авторка Ненсі Стауффрер написала декілька книжок, в одній із них описувалися істоти під назвою «магли», в іншій книзі ім'я головного героя було «Ларрі», за зовнішніми характеристиками він носив окуляри і мав коричневе волосся. Після виходу першої книги Джоан Роулін про Гаррі Поттера американська авторка звернулася до американського видавця книг Джоан Роулінг щодо порушення ㄲï авторського права. Американський видавець, в свою чергу, подав позов до Південного округу Нью-Йорка вимагаючи встановлення порушення. ${ }^{1}$

Суд, проаналізувавши всі деталі вимог сторін, прийшов до висновку, що подібність між книгами Ненсі Стауффрер та Джоан Роулінг є мінімальною та поверхневою, і навіть якщо розглядати в цілому, це не могло б призвести до ймовірності 
плутанини. Адже стосовно маглів, у американської авторки ці істоти були крихітними, безволосими та 3 видовженими головами, які живуть у вигаданій, постапокаліптичній землі. Стосовно твердження подібності імен героїв «Ларрі та Гаррі», - суд встановив, що описані герої з окулярами не були достатніми для створення ймовірності плутанини або значної подібності з метою захисту авторських прав. I оскільки ймовірність плутанини є необхідним елементом позовів, суд задовольнив клопотання американського видавця Джоан Роулінг - про щодо відхилення цих вимог. Крім того, суд зазначив, що немає жодних доказів, які б свідчили, що або Роулінг, або Мері Грандпре, ілюстратор, який створив обкладинки Гаррі Поттера, коли-небудь мали доступ до робіт Стауфффер до цього судового процесу. Адже твердження Стауффрер про те, що Роулінг мала все-таки доступ до їі робіт базувалися на двох непрямих доказах: по-перше, те, що деякі роботи Стауффрер демонструвались на ярмарку іграшок у Нюрнберзі, - в Німеччині в 1987 році; по-друге, книги Стауфффер були доступні через компанію Роулінг в Чеширі, Англія. Однак не було жодних доказів того, що Роулінг відвідувала ярмарок іграшок в Нюрнберзі, адже це положення Стауффрер грунтувалося виключно на тому, що Роулінг жила в Свропі, коли ярмарок відбувся. Що стосується магазину в Чеширі в Англії, в якому Роулінг могла мати доступ до робіт Стаудpdep, однак і в тому випадку не було жодних доказів, що компанія, на яку посилалася позивачка у своїх зустрічних позовах, коли-небудь продавала її майно, і навіть жодних доказів того, що компанія управляла магазином. Крім того, клопотання про санкції, подані Стауффрер, грунтувалися на шахрайстві проти Суду, адже вона в зустрічних позовах подала щонайменше сім фральсифрікованих доказів, наприклад, змінені копії сценаріїв їі книжок і так далі. Зрештою, внаслідок вчинення цих шахрайстф Стаудрер була змушена заплатити санкцію в розмірі 50000 доларів.

Наступна з гучних справ, пов'язаних з Гаррі Поттером, була справа компанії Warner Bros. v. RDR Books. У 2002 рощі Стівен Вандер Арк створив сайт «Лексикон Гаррі Поттера». Цей сайт включає окремі цитати та певні висновки 3 сюжетів книжок Роулінг. Цікаво, що сама Роулінг використовувала цей сайт також. Пізніше невелике видавництво в Маскегоні, штат Мічиган RDR Books погодилося видати Лексикон Стівена Вандера у книжковій формі у вигляді енциклопедії. В свою чергу, видавництво пішло в наступ та також подало зустрічні позови. Роулінг разом 3 видавництвом подала позов до суду стосовно припинення публікащії книги. Важливим моментом в цій справі було те, що Роулінг планувала написати власну енциклопедію, кошти від якої були б пожертвувані на благодійність. Основне питання в суді було приділене саме добросовісному використанню роману Роулінг.

Суд встановив, що сам Лексикон не $є$ похідним твором. Однак заборонив видавати книгу, адже Лексикон скопіював текст Роулінг таким чином, що це би унеможливлювало належне використання та попит на енциклопедію Роулінг пізніше. Сам сайт мав некомерційне призначення, однак видання книги створювало би комерційне підірунтя. Тому книга у вигляді енциклопедіі безперечно конкурували би з власною енциклопедією про Гаррі Поттера Роулінг. Тому, - суд постановив, що неопублікована книга «Лексикон» порушила роботу Роулінг [5, с. 430-434].

Питання, в цілому, фран-творів завжди межує з порушенням авторських прав. Тому в таких випадках завжди виникає два питання: чи захищена певна робота авторським правом, а по-друге, чи порушуе такий фран-твір авторські права на оригінальний твір.

Відповідаючи на перше питання, слід сказати, що визначення строку охорони авторського права не завжди може бути легким. Різке розширення тривалості авторського права в минулому столітті здійснило тривалість середнього терміну авторського права довше, ніж тривалість середнього життя людини. Для прикладу роботи Артура Конан Дойля, а особливо історії про Шерлока Холмса та «Загублений світ», - активно використовуються франатами та офрормлюються у комерційно видані роботи. «Загублений світ» був опублікований у 1912 рощі, сам автор помер у 1930 році. Спочатку перший термін дії авторських прав закінчився в 1940 році, а оновлений термін закінчився в 1968 році, і саме після цього цей твір увійшов до суспільного надбання в США. Враховуючи, що «Загублений світ» $е$ загальнодоступним у США, інші автори можуть вільно публікувати похідні твори на їх основі.

Друге питання полягає у тому, чи порушує безпосередньо фран-твір авторські права, імітуючи оригінальний твір, у випадку, коли твори чи персонажі захищені авторським правом. В певному літературному сенсі, - фран-твір є похідним твором, він не може існувати без оригінального. Тому, фран-твір може не в меншій мірі порушувати права та інтереси правоволодільця оригінального твору. Адже, якщо новий твір є похідним, то володілець прав на оригінальний твір має виключне право контролювати виготовлення та розповсюдження похідного твору, які не можуть здійснюватися без його дозволу. Однак, варто підкреслити, що більшість фран-творів створюються з метою розваги автора, шанувальників та не мають комерційної мети. Тому, в такому випадку, некомерційне обмежене використання похідного твору може не визнаватися порушенням авторських прав [5, с. 395-399].

Висновки 3 даного дослідження i перспективи. Таким чином, акцентуючи увагу на поняттях «плагіат» та «порушення авторського права», можна прийти до висновку, що «плагіат» не $е$ тотожним поняттю «порушення авторського права", водночас вони можуть збігатися. Однак саме «плагіат» буде розглядатися в контексті етичної конструкції і відповідальність можуть визначати академічні установи, комісї, а «порушення авторського права» буде розглядатися виключно 3 правової точки зору і відповідальність встановлюватиметься судом. Розглядаючи справи, пов'язані з питаннями подібності робіт позивача та відповідача, а також питання доступу та привласнення робіт позивача на прикладі системи США, можна стверджувати, що фракт подібності конкретних двох творів, - не завжди є безсумнівним доказом літературного плагіату. Судова практика виходить 3 того, що така по- 
дібність повинна бути «виняткова», а не «суттева», хоча ці два поняття завжди будуть досить суб'єктивними. Така подібність повинна слугувати фрактором «ймовірності плутанини», тоді вона стає необхідним елементом позовів. Якщо вона не створюе такого фрактору, то тоді будь-які докази вважатимуться непрямими. Слід наголосити на тому, що, якщо певні фран-твори створюються 3 метою розваги як автора, так і шанувальників та не мають комерційної мети, - може бути дозволеним некомерційне обмежене використання твору і це не буде порушенням авторських прав.

В цілому, питання, які виникають у сфері захисту об'ектів прав інтелектуальної власності стають все більше актуальними. Науково-технічний прогрес та розвиток суспільства безпере- чно це прискорюють. Ринкова економіка сприяє тому, щоб об'єкти інтелектуальної власності і механізми їх захисту все більше підпадали під ефрективне правове забезпечення. Безумовно, належний захист авторського права має неабияке стратегічне значення. Проте все частіше з'являються недобросовісні суб'єкти, які порушують права інших правоволодільців об'єктів прав інтелектуальної власності. З'являється все більша кількість прецедентних справ у зв'язку з порушенням авторських прав вже відомих авторів i, в таких випадках, з'являеться так зване поле для зловживання. Саме в таких справах цікавими і важливими є певні деталі, на які суди приділяють увагу і які $е$ ключовими при прийнятті судових рішень.

\section{Список літератури:}

1. Reid M. Harry Potter and the Copyright Act: Have the Courts Finally Waved a Magic Wand by Defining Fair Use for Secondary Authors. Villanova University Charles Widger School of Law Digital Repository. 2009. Pp. 1-5.

2. Buttler III G.F. Warner Bros. Entertainment and J.K. Rowling v. RDR Books and Does 1-10 575 F. Supp. 2 D 513. DePaul Journal of Art, Technology \& Intellectual Property Law. 2009. Pp. 1-5.

3. Harms L.T.C. A Casebook on the Enforcement of Intellectual Property Rights. World Intellectual Property Organization. 2018. Pp. 71-86.

4. Schwabach A.The Harry Potter Lexicon and the World of Wandom: fan fiction, outsider works, and copyright. University of Pittsburgh Law Review. 2009. Pp. 8-9, 25-29.

5. Peck D.L. Copyright Infringement of Literary Works. An Elemental Analysis. Marquette Law Review. 1955. Pp. 181-191.

6. Романова І.В. Явище плагіату: історія та сьогодення. Зовнішня торгівля: право, еконоліка, фбінанси. 2012. № 3. C. 269-271.

7. Sengupta S.S. Copyright infringement and Plagiarism: are they really two sides of a coin?. Department of Library \& Information Science C.T. Bora College. 2015. Pp. 20-22.

\section{References:}

1. Reid M. (2009) Harry Potter and the Copyright Act: Have the Courts Finally Waved a Magic Wand by Defining Fair Use for Secondary Authors. Villanova University Charles Widger School of Law Digital Repository, pp. 1-5.

2. Buttler III G.F. (2009) Warner Bros. Entertainment and J.K. Rowling v. RDR Books and Does 1-10 575 F. Supp. 2D 513. DePaul Journal of Art, Technology \& Intellectual Property Law, pp. 1-5.

3. Harms L.T.C. (2018) A Casebook on the Enforcement of Intellectual Property Rights. World Intellectual Property Organization, pp. 71-86.

4. Schwabach A. (2009) The Harry Potter Lexicon and the World of Wandom: fan fiction, outsider works, and copyright. University of Pittsburgh Law Review, pp. 8-9, 25-29.

5. Peck D.L. (1955) Copyright Infringement of Literary Works. An Elemental Analysis. Marquette Law Review, pp. 181-191.

6. Romanova I.V. (2012) Yavyshche plahiatu: istoriia ta sohodennia [The phenomenon of plagiarism: history and present]. Zovnishnia torhivlia: pravo, ekonomika, finansy, no. 3, pp. 269-271.

7. Sengupta S.S. (2015) Copyright infringement and Plagiarism: are they really two sides of a coin? Department of Library \& Information Science C.T. Bora College, pp. 20-22. 